\title{
The Attributes of Japanese Corporate Governance Influencing the Quality of Internal Controls
}

\author{
Hiroshi Uemura ${ }^{1}$ \\ ${ }^{1}$ School of Economics and Management, Kochi University of Technology, Kochi, Japan. \\ Correspondence: Hiroshi Uemura, School of Economics and Management, Kochi University of Technology, Kochi, \\ Japan.
}

Received: January 14, 2016

Accepted: January 28, 2016

Available online: January 29, 2016

doi:10.11114/afa.v2i1.1342

URL: http://dx.doi.org/10.11114/afa.v2i1.1342

\begin{abstract}
This study examines the corporate governance characteristics that influence the improvement in the quality of internal controls. Previous studies suggest that corporate governance independence and expertise affect the quality of internal controls (Krishnan et al. 2005; Hoitash et al. 2009). In Japan, however, any company that discloses significant deficiencies (SD) in internal controls has the motive to increase the independence of corporate governance to mitigate any subsequent negative consequences. As a result, independent directors are made the scapegoats, rather than allowing them to fulfill the expectation of improvement in the quality of internal controls. On the other hand, directors with financial expertise that have a high status in a company do influence the improvement in SD in internal controls. This suggests that in Japan it is important to provide financial experts with the power and authority to improve the quality of internal controls in the short term, due to the difference in the provisions between the Financial Instruments and Exchange Act (J-SOX) and the Sarbanes-Oxley Act (SOX). The requirements in Japanese Corporate Law (JCL) for independent directors are not as strict as those within SOX. Therefore, companies in which the boards are able to promote expert directors to important positions improve the quality of internal controls more often than those that are not. It is thus revealed that auditors should be able to discuss with the financial experts as to what is required to improve any significant deficiencies that are detected in the process of internal control audits.
\end{abstract}

Keywords: internal control deficiencies, corporate governance independence, corporate governance expertise

\section{Introduction}

\subsection{Background}

This study examines corporate governance characteristics influencing the improvement in the quality of internal controls. In Japan, the Financial Instruments and Exchange Act of 2006 (J-SOX) requires all listed companies to disclose management reports on internal controls over financial reporting (management's assessment of the effectiveness of internal controls over financial reporting) and audit reports on the management reports (J-SOX Section 24 and Section 193). ${ }^{1}$ J-SOX also prescribes that significant deficiencies (SD) that are not improved by fiscal year end must be disclosed in management reports. After Sarbanes-Oxley Act of 2002 (U.S. SOX), some previous studies suggest that corporate governance independence and expertise affect improvement in the quality of internal controls (Krishnan et al. 2005; Hoitash et al. 2009). However, because Japanese corporate governance structure, which depends on domestic legislation (Japanese corporate law: JCL and the J-SOX), has different characteristics from those of the US, corporate governance attributes that can improve the quality of internal controls may also differ.

In recent years, some serious accounting scandals occurred in Japan (e.g., the Olympus Accounting Fraud), which had an enormous impact on the Japanese stock market. Moreover, public criticism following these scandals turned on JCL, J-SOX and corporate governance of Japanese listed companies. The quality of corporate governance, in particular governance independence, was considered to be the problem, and public opinion expected the government to amend JCL (i.e., the provision related to the requirements for independent directors).

\footnotetext{
1 J-SOX does not require auditors to directly assess the effectiveness of clients' internal controls. Instead, auditors must judge the validity of the management report. That is, based on the audit evidence that the auditors themselves obtain, they express their opinion on whether the management report is fair. Therefore, Japanese internal control audits do not adopt direct reporting.
} 
The Ministry of Justice of Japan proposed a tentative draft that required a listed company to appoint one or more outside directors. ${ }^{2}$ This move had an argument behind this plan, in that more governance independence meant more of a possibility that governance monitoring will detect accounting fraud. Indeed, the results of some previous studies support this assumption (Krishnan et al. 2008; Hoitash et al. 2009), indicating that the quality of corporate governance (governance independence and expertise) has a positive correlation with the quality of internal controls. Monitoring is one of the components of internal controls, and the quality of corporate governance refers to effectiveness of that monitoring. Because the governance independence influences the effectiveness of monitoring, companies with a high level of governance independence do not disclose significant deficiencies in internal controls.However, in Japan, there is a possibility that the relationship between governance independence and the effectiveness of monitoring (internal control quality) differs from that in the U.S. The focus of corporate governance studies is on the foundation of agency theory, and these studies examine how the monitoring roles of the boards are used to protect stockholder's rights (Cohen et al., 2008). However, in Japan, board roles cannot be discussed on the basis of merely agency theory. There are two reasons for the argument. First, the requirements for independent directors within JCL are not as strict as those in the US. For example, in the US, a director is not regarded as independent if he/she is a current employee or a close relative of a current executive officer of an organization that has either made payments to or received payments from the listed company for a property or services for an amount that, in any of the last three fiscal years, exceeds more than $\$ 1$ million or $2 \%$ of the company's consolidated gross revenues. ${ }^{3}$ Such a strict requirement does not exist in JCL. According to JCL, a director who is a parent company's employee, and a director who is a client company's employee is regarded as outside (JCL, 2. 15). Therefore, in Japan no outside directors exist on board of directors, or outside of the persons involved in the same group (a main bank, a subsidiary company, etc.) in many cases.

Second, U.S. SOX requires that a member of the audit committee should be an independent director (SOX Section 301) and that the committee should include one or more financial expert member (SOX Section 407). That is, U.S. SOX prescribes the requirement for governance independence and expertise. In contrast, the same provisions are not present in JCL or J-SOX; instead, governance independence (the number of outside directors) and expertise (the level of experience and knowledge of governance members) are left to the board's (or top management's) discretion. Although JCL has provisions regarding the requirements for director from outside, they do not force the company to include independent directors on the board. Moreover, there is no provision concerning the requirements of board member's expertise in JCL. Because the extent of independence and expertise of the board is arranged by management's discretion, it is difficult to believe that the board plays a role for shareholders.

In sum, this study assumes that the characteristics of Japanese corporate governance influence the quality of internal controls. The so-called "Anglo-Saxon corporate governance model" emphasizes a single-tiered board of directors composed of executives from the company and non-executive officers, all of whom are elected by shareholders. Non-executive officers are expected to outnumber executive directors and hold key posts, including the audit and compensation committees. In contrast, because CEOs of most Japanese companies hold the position of chairman of the board, CEOs almost conduct operations of corporate governance (Uemura, 2013). In fact, although Toshiba is a company with a committee governance structure, outside directors that composed committees have connived at an accounting dishonesty of their CEO.

This study examines the relationship between corporate governance quality (independence and expertise), as determined by the board, and the internal control quality. If the result indicates that although governance independence does not influence internal control quality, the other factor-governance expertise — does, regulators will have to make new provisions. In other words, it is necessary to make new provisions that prescribe corporate governance quality (including the both governance independence and expertise).

In this study, the ratio of outside directors is used as a proxy for governance independence. ${ }^{4}$ Also, governance expertise is measured by financial, internal audit, and internal control expertise, and the status of any director is used as a proxy for the governance expertise level. For example, if a company has a CFO (a financial expert) who is also a vice president (a top position), we can think that the governance expertise in this company is high. Moreover, the quality of internal controls is measured by the possibility that a significant deficiency exists in internal controls (not the disclosure of a significant deficiency). This study utilizes the model for the determinants of significant deficiencies (or material weaknesses) from previous studies (Ge and McVay 2005; Doyle et al. 2007a; Ashbaugh et al. 2007) to computes the possibility.

\footnotetext{
2 However, the plan aroused fierce opposition among the business community and was abandoned.

3 The NYSE Listed Company Manual (303A.02, Independence Test (b), (v)).

${ }^{4}$ In this study, the independent directors include outside directors and corporate auditors (or audit committee members). In Japan, the number of companies that have established an audit committee is relatively low, and many of them have a corporate auditor system instead.
} 
The empirical result indicates that outside directors are made scapegoats, rather than allowing them to fulfill the expectation to improve the quality of internal controls (corporate governance independence has a positive correlation with the possibility of existing significant deficiencies). On the other hand, directors with financial expertise that are placed at a high position in a company do influence the improvement in significant deficiencies. This suggests that in Japan it is important to provide financial experts with the power and authority in order to improve the quality of internal controls in the short term. Moreover, companies in which the boards promote expert directors to important positions improve the quality of internal controls more often than those that do not practice such promotion. This reveals that auditors should be able to discuss with these financial experts as to what is required to improve any significant deficiencies that are detected in the process of internal control audits.

\subsection{Prior Reserch Studies and Hypotheses}

Previous studies assume that the attributes of the corporate governance influence the quality of internal controls. In Japan, the board can decide themselves whether the board includes an independent director as a board member and how many independent directors does the board hire. Because of that, there are no provisions related to the enforcement the independence of the chairman of the board in JCL. Also, although JCL provides requirements that a director should fulfill as an outside director (JCL section 2 (15)), it does not provide a provision to force companies to include the outside directors or the accounting expert directors as board members. ${ }^{5}$ Moreover, the requirements for independent directors in JCL are as not strict as those in the U.S. In Japan, a director who is a parent company's employee, and a director who is a client company's employee is regarded as outside (JCL, 2. 15). Therefore, in Japan no outside directors exist on board of directors, or outside of the persons involved in the same group (a main bank, a subsidiary company, etc.) in many cases. Under this situation, assuming that the independence of corporate governance influences the quality of internal controls is difficult.

Miyajima and Ogawa (2012) examine the determinants of Japanese governance independence (outside directors ratio, number of external directors, and new election of external directors). The empirical result indicates that business complexity (total assets, the number of business segments) and adoption of anti-takeover measures (e.g., poison pill) have positive correlation with governance independence. Moreover, Saito (2011) and Uchida (2012) show that financial risk also has a positive correlation with governance independence.

Furthermore, Uemura (2013) suggests that the disclosure of significant deficiencies has a positive correlation with governance independence (ratio of outside directors). Interestingly, the ratio of outside directors in the disclosure year was higher than that in the previous one, suggesting that the boards of directors that disclose significant deficiencies have a motive to increase governance independence, i.e., in order to mitigate any subsequent negative consequences. The disclosure of significant deficiencies does cause some serious economic consequences, such as the negative reaction in stock market (Beneish et al. 2008; Hammerseley et al. 2008) and the rising cost of capital (Ogneva et al. 2007; Beneish et al. 2008). Moreover, companies that disclose significant deficiencies have a more frequent turnover of their executives (Uemura 2012). These results are referred to as the risks of disclosure of significant deficiencies in internal controls (RDSD). It is proposed that the governance independence of companies in which RDSD is high is greater than those of companies in which it is not. This leads the first hypothesis.

\section{H1: Corporate Governance independence is greater in companies where internal controls quality is low than that in companies where quality is high.}

Krishnan et al. (2005) focus on the relationship between the quality of corporate governance (governance independence and expertise) and the quality of internal controls (auditor resignations resulting from internal controls issues). Governance expertise is measured by the number of audit committee members who were public accountants or tax professions. The result indicates that the expertise of the audit committee had a negative correlation with the auditor resignations related to internal controls problems.

Hoitash et al. (2009) also examine the relationship between the expertise of the audit committee and the internal controls quality and identify both management and accounting expertise among committee members' experience. Following are the three main findings in this study: first, the accounting expertise of the audit committee has a negative correlation with the disclosure of deficiencies in the financial reporting process; second, management expertise has a negative correlation with the existence of deficiencies in the management process; and third, the expertise of the audit committee has a negative correlation with the disclosure of significant deficiencies. Therefore, the expertise of the audit committee influences the quality of internal controls. The results are supported by Balsam and Jiang (2009).

\footnotetext{
5 If a company has committee boards, a majority of committee members should be outside directors (JCL section 400(3)). However, out of companies listed in Tokyo Stock Exchange $(2,275)$, the number of the companies that have committee boards is only 49 companies (2.15\%).
} 
The results of previous studies cannot explain the governance attributes that influence internal controls quality and its improvement. As stated in the Introduction, there are few companies that have audit committees in Japan, with most having a corporate auditor system as their internal monitoring system instead. Under JCL, corporate auditors are ordinary employees of the company with less authority; although, they play a role in monitoring operations, they have no voting rights because they are independent of the board of directors and have no authority to manage and instruct employees.

Therefore, the board's views are important in ensuring governance expertise. In other words, if the board understands the importance of governance expertise for monitoring effectiveness, then it will probably exercise its discretion to promote expert directors to higher-status. It is proposed that the monitoring of quality in a company is greater where expert directors are placed in high-status than in a company where they are not placed so. This leads the second hypothesis.

H2: The quality of internal controls in companies with higher corporate governance expertise (high-expertise companies) is greater than in those with lower corporate governance expertise.

\section{Method}

\subsection{Mesurement of Internal Controls Quality}

Previous studies have clarified the determinants of the disclosure of SD: company size, complexity, financial risk, and audit firms' size (Ge and McVay 2005; Doyle et al. 2007; Ogneva 2007; Ashbaugh 2007). However, in Japan there are few companies that disclosed SD after introducing an internal controls audit. In fact, of the 2,437 listed companies that submitted management reports for the fiscal year ending March 2009 (the first year of internal controls audit), only 57 (2.33\%) disclosed SD. ${ }^{6}$ In the US literatures, nondisclosure of SD means they have been remediated. However, believing that most Japanese companies with SD in internal controls during that fiscal year remediated them by the fiscal year end is difficult. J-SOX does not require auditors to directly assess the effectiveness of clients' internal controls. Instead, auditors judge the validity of the management report (management's assessment of the effectiveness of internal controls). In this situation, the materiality threshold of deficiencies in internal controls may be different between auditors and managements. Moreover, through discussion of auditor and management in internal control audit, auditors' final judgments of the materiality threshold may be affected by managements' materiality threshold. To remove influence of the management's materiality, companies that have a RDSD (not disclose SD) need to be clarified. This study uses the model for the determinants of SD to calculate RDSD (the discrimination analysis method).

The prior probability that a company belongs to the significant deficiencies disclosure group $\left(\omega_{1}\right)$ on the condition that the discrimination function (model for the disclosure of significant deficiencies) (z) is given as:

$$
p\left(\omega_{1} \mid z\right)=p\left(\omega_{1}\right) p\left(z \mid \omega_{1}\right)=p(x) p\left(\omega_{1} \mid z\right)
$$

Where, $z=S D_{t}=$

$$
\begin{aligned}
& f\left({ }_{0}+{ }_{1}\left(\text { LNSize }_{t}\right)+{ }_{2}\left(M \& A_{t}\right)+{ }_{3}\left(\text { LNSub }_{t}\right)+{ }_{4}\left(\text { ForeignSales }_{t}\right)\right. \\
& +{ }_{5}\left(\text { ROA }_{t}\right)+{ }_{6}\left(\operatorname{Re} \text { state }_{t}\right)+{ }_{7}(G C)+{ }_{8}(C f O / A) \\
& +{ }_{9}\left(\text { Big }_{t}\right)+{ }_{10}\left(\text { AudChange }_{t}\right)+{ }_{11}\left(\text { Found }_{t}\right)+{ }_{12}\left(\text { LNDirectors }_{t}\right) \\
& \left.+{ }_{13}\left(\text { Office }_{t}\right)+{ }_{14}\left(\text { ExeChange }_{t}\right)\right)
\end{aligned}
$$

Therefore, the posterior probability that a company belongs to $\left(\omega_{1}\right)$ is

$$
p\left(\omega_{1} \mid z\right)=\frac{p\left(\omega_{1}\right) p\left(z \mid \omega_{1}\right)}{p(z)}
$$

This study computes RDSD of any company on the basis of equation (3) (not the disclosures of significant deficiencies) to identify internal control quality. Moreover, the result of the linear discrimination function is calculated by inputting the sample data into equation $(2)^{7}$ and, the coefficients of each variable in the function were calculated, taking the $z$ function as follows:

\footnotetext{
${ }^{6}$ In the US, $23.5 \%$ companies disclosed material weaknesses in the first year.

7 Wilks $\Lambda=0.740(\mathrm{p}<0.001), \chi^{2}=584.20, d f=14$.
} 


$$
\begin{aligned}
z=2.397 & +\left(-0.122 * \text { LNSize }_{t}\right)+\left(0.278 * M \& A_{t}\right)+\left(0.199 * \text { LNSub }_{t}\right)+\left(0.002 * \text { ForeignSals }_{t}\right) \\
& +\left(-0.001 * \text { ROA }_{t}\right)+\left(0.603 * \text { Restate }_{t}\right)+(2.542 * \text { GC })+(-0.011 * \text { CfO/ A }) \\
& +\left(-0.483 * \text { Big }_{t}\right)+(0.931 * \text { AudChange })+\left(-0.001 * \text { Found }_{t}\right) \\
& +\left(-0.480 * \text { LNDirectoIs }_{t}\right)+\left(-0.042 * \text { Office }_{t}\right)+(0.217 * \text { ExeChange })
\end{aligned}
$$

Finally, $z$ was input into equation (3), and the posterior probability calculated, which indicated the possibility that a company had a significant deficiency during the fiscal year. Therefore, if a company, in spite of a high probability, had not disclosed a significant deficiency, then their remediation had succeeded. The details of each of the above variables are described in Table 1. Table 2 shows the number of companies where the posterior probability was $50 \%, 30 \%$, and $20 \%$, as well as the number of companies disclosing significant deficiencies. In the third line from the top, \% depicts the ratio of the number of companies with $50 \%, 30 \%$, and $20 \%$ probability to the full sample. This study identifies the threshold for low-quality internal controls on the basis of the American result as 20\% (posterior probability 20\%; hereafter, PSD $(20 \%)$ ), because the ratio of the number of companies with $20 \%$ probability to the full sample is $15.7 \%$.

\subsection{Mesurement of Corporate Governance Expertise}

Uemura (2013) examines the disclosure of significant deficiencies and governance expertise, and the result shows that the ratio of outside directors and corporate auditors in companies that disclosed significant deficiencies was higher than that in nondisclosure companies. On the other hand, the status of expert director has a negative correlation with the disclosure of significant deficiencies. Uemura (2013) constructs the score model for measuring governance expertise, which is used in this study. In this model, the scores of governance members depict the level of authority each holds within the organization, and therefore, the level of governance expertise. The equation is as follows:

Governance expertise score* $=$

(Total number of directors +1$)-($ expert directors $* *$ post order $)$

*at the fiscal year end, if a company has not arranged for expert directors,

then its governance expertise score is 0 .

**expert directors: financial directors, internal audit directors, and internal controls directors.

\subsection{Sampling Procedures}

\subsubsection{Sample}

The NEEDS Financial Quest and EDINET Online databases are used to identify financial data from March 31, 2009 through December 31, 2011. Financial data are available for 9,338 firm-years; all the listed companies account for 10,852 firm-years. Of all these companies, 511 companies that belong to the finance, securities, and insurance sector, 510 companies for which there is no financial data available, and 493 companies that have not made their governance data available are all eliminated. From the remainder, 139 companies disclosed significant deficiencies, while 23 companies did not disclose any data related to their internal controls effectiveness because they could not assess them. Table 3 summarizes the sample selection.

\subsubsection{Model}

The probit models are used to test the relationship between governance independence and internal controls quality are based on those by Saito (2011), Miyajima and Ogawa (2012), and Uchida (2012). The dependent variables are the ratios of outside directors $\left(O U T S I D E_{-} D_{t}\right)$ and outside corporate auditors $\left(O U T S I D E_{-} A_{t}\right)$. The disclosure of significant deficiencies $\left(S D_{t}\right)$ and the posterior probability $20 \%(P S D 20 \%)$ are the independent variables of interest. The models are as follows:

$$
\begin{aligned}
& \operatorname{Prob}\left(O U T S I D E_{-} D_{t}\right)=F\left(\alpha+\beta_{1} S D_{t}+\beta_{2} F R_{t}+\beta_{3} L N S I Z E_{t}+\beta_{4} M \& A_{t}+\beta_{5} F O R E I G N_{t}\right. \\
& +\beta_{6} L N S U B_{t}+\beta_{7} R O A_{t}+\beta_{8} G C_{t}+\beta_{9} C A_{t}+\beta_{10} D_{-} O W N_{t} \\
& \left.+\beta_{11} O F F I I C E_{t}+\beta_{12} D E B T_{t}+\beta_{13} S E C_{t}\right) \\
& +\beta_{6} L_{N S U B_{t}}+\beta_{7} R O A_{t}+\beta_{8} G C_{t}+\beta_{9} C A_{t}+\beta_{10} D_{-} O W N_{t} \\
& \left.+\beta_{11} O F F I I C E_{t}+\beta_{12} D E B T_{t}+\beta_{13} S E C_{t}\right)
\end{aligned}
$$




$$
\begin{aligned}
& \operatorname{Prob}\left(\text { OUTSIDE } D_{t}\right)=F\left(\alpha+\beta_{1} \text { PSD } 20 \%_{t}+\beta_{2} F R_{t}+\beta_{3} \text { LNSIZE }_{t}+\beta_{4} \text { M\&A }_{t}+\beta_{5} \text { FOREIGN }_{t}\right. \\
& +\beta_{6} \text { LNSUB }_{t}+\beta_{7} R O A_{t}+\beta_{8} G C_{t}+\beta_{9} C A_{t}+\beta_{10} D_{-} O W N_{t} \\
& \left.+\beta_{11} \text { OFFIICE } E_{t}+\beta_{12} D E B T_{t}+\beta_{13} S E C_{t}\right) \\
& +\beta_{6} L N S U B_{t}+\beta_{7} R O A_{t}+\beta_{8} G C_{t}+\beta_{9} C A_{t}+\beta_{10} D_{-} O W N_{t} \\
& \left.+\beta_{11} \text { OFFIICE } E_{t}+\beta_{12} D E B T_{t}+\beta_{13} S E C_{t}\right)
\end{aligned}
$$

The model to test the relationship between governance expertise and internal controls quality is based on that by Ge and McVay (2005), Ashbaugh et al. (2007), and Uemura (2013). The dependent variable is the disclosure of significant deficiencies, and the governance expertise scores $\left(E X P E R T_{-} F(S C)_{t}\right),\left(E X P E R T_{-} I C(S C)_{t}\right)$, and $\left(E X P E R T_{-} I A(S C)_{t}\right)$ are the independent variables of interest. The logistics regression model is as follows:

$$
\begin{aligned}
& S D_{t}=F\left({ }_{0}+{ }_{1} E X P E R T_{t-} F(S C)_{t}+{ }_{2} E X P E R T_{-} I C(S C)_{t}+{ }_{3} E X P E R T \_I A(S C)_{t}\right. \\
& +{ }_{4} F R_{t}+{ }_{3} M \& A_{5 t}+{ }_{6} F_{\text {FOREIGN }}+{ }_{7} \text { LNSUB }_{t}+{ }_{8} \text { LNSIZE }_{t} \\
& +{ }_{9} R O A_{t}+{ }_{10} G C_{t}+{ }_{11} B I G 4_{t}+{ }_{12} \text { AUDITORS }_{t} \text { ) }
\end{aligned}
$$

Definitions of the variables in models are provided in Table 4.

\section{Results}

\subsection{Descriptive Statistics}

Table 5 shows that the descriptive statistics for the variables included in the model that distinguishes between a low-quality group (companies that have low-quality internal controls) and a control group. First, outside directors ratio $\left(O U T S I D E \_D_{t}\right)$, external corporate auditors ratio $\left(O U T S I D E \_A_{t}\right)$, and the dummy variable of the corporate auditors ratio is greater than or equal to $50 \%\left(O U T S I D E_{-} A 50 \%_{t}\right)$ in the low-quality group are higher than those in the control group $(\mathrm{t}=7.75(\mathrm{p}<0.001), \mathrm{t}=17.20(\mathrm{p}<0.001), \mathrm{t}=13.35(\mathrm{p}<0.001)$, respectively $)$.

Second, firm size $\left(L N S I Z E_{t}\right)$ in the low-quality group is smaller than that in the control group $(\mathrm{t}=21.56(\mathrm{p}<0.001))$. In addition, financial risks (financial restatement $\left(F R_{t}\right)$ ), return on assets $\left(\mathrm{ROA}\left(R O A_{t}\right)\right.$ ), and the dummy variable of going concern $\left(G C_{t}\right)$ in the low-quality group are higher than in the control group $(\mathrm{t}=53.01(\mathrm{p}<0.001), \mathrm{t}=3.72(\mathrm{p}<0.001)$, $\left.\chi^{2}=17.44(\mathrm{p}<0.001)\right)$.

Third, company age in the low-quality group $\left(C A_{t}\right)$ and the directors' length of term in office $\left(O F F I C E_{t}\right)$ are smaller than those in the control group $(\mathrm{t}=14.31(\mathrm{p}<0.001), \mathrm{t}=12.34(\mathrm{p}<0.001))$. On the other hand, the control group's debt ratio $\left(D E B T_{t}\right)$ and shareholding ratio of directors $\left(D_{-} O W N_{t}\right)$ are smaller than those in the low-quality group $(\mathrm{t}=3.62(\mathrm{p}$ $<0.001), \mathrm{t}=11.98(\mathrm{p}<0.001))$.

Next, the auditor firms' size $\left(B I G 4_{t}\right)$ and the number of auditors (AUDITORS $\left.t\right)$ in the audit team are smaller in the low quality than those in the control group $(\mathrm{t}=25.19(\mathrm{p}<0.001), \mathrm{t}=8.71(\mathrm{p}<0.001))$.

Finally, the possibility that companies in the control group has an expert financial director $\left(E X P E R T_{-} F_{t}\right)$, internal control expert director $\left(E X P E R T_{-} I C_{t}\right)$, and internal audit expert director $\left(E X P E R T_{-} I A_{t}\right)$ is higher than that in the low-quality group. These results support $\mathrm{H} 1$ and $\mathrm{H} 2$.

Table 6 shows that the correlation matrices $\left(O U T S I D E \_D_{t}\right)$ and $\left(O U T S I D E_{-} A_{t}\right)$ have a positive correlation with $\left(P S D 20 \%_{t}\right)$, and that $\left(E X P E R T_{-} F_{t}\right)$ and $\left(E X P E R T_{-} I A_{t}\right)$ have a negative correlation with $\left(P S D 20 \%_{t}\right)$. Also, these results support $\mathrm{H} 1$ and $\mathrm{H} 2$.

\subsection{Probit Regression Analysis (Governance Independence and Internal Controls Quality)}

From the second to seventh column in Table 7 the result of the probit analysis testing H1 based on models (5) and (7) $\left(\chi^{2}=2.45(\mathrm{p}=0.12), \chi^{2}=3.02(\mathrm{p}=0.19)\right)$ can be seen. It shows that a statistically significant positive correlation between $\left(S D_{t}\right)$ and $(P S D 20 \%)$ also has a statistically significant positive correlation with $\left(O U T S I D E_{-} D_{t}\right)(z=2.47(\mathrm{p}=$ $0.023), z=2.31(\mathrm{p}=0.027))$, which supports H1.

The eighth to thirteenth column in Table 7 show the result of the probit analysis based on models (6) and (8) $\left(\chi^{2}=3.78\right.$ $\left.(\mathrm{p}=0.22), \chi^{2}=6.55(\mathrm{p}=0.34)\right)$. It shows that $\left(P S D 20 \%_{t}\right)$ has a statistically significant positive correlation with $\left(O U T S I D E \_D_{t}\right)(z=5.43(\mathrm{p}<0.001)$. The result further supports $\mathrm{H} 1$ in that companies with low-quality internal controls have the motive to enhance governance independence because the disclosure of significant deficiencies brings serious economic consequences. On the other hand, this can also be alternatively understood that the independence of directors functioned and it could lead to the disclosure of internal control deficiencies. In an additional analysis, however, the result indicates that firms enhancing board independence are less likely to remediate disclosed significant 
deficiencies. ${ }^{8}$ Therefore, outside directors are made scapegoats, rather than allowing them to fulfill the expectation to improve the quality of internal controls.

\subsection{Logistics Regression Analysis (Governance Expertise and Internal Controls Quality)}

The second to fourth columns in Table 8 show the result of the logistics regression analysis for testing $\mathrm{H} 2$ based on model (9) (Hosmer-Lemeshow: $\chi 2=8.02(\mathrm{p}=0.22)$; Cox-Snall: $\mathrm{R}^{2}=0.051(\mathrm{p}=0.122)$, $\left.\mathrm{df}=8\right)$. It shows that $\left(E X P E R T_{-} F(S C)_{t}\right)$ has a significant negative correlation with $\left(S D_{t}\right)($ Wald $=4.31(\mathrm{p}=0.035))$, implying that if an expert financial director holds authority within an organization, then the quality of internal controls is improved by the fiscal year end. This result supports H2. However, $\left(\right.$ EXPERT_IC $\left.(S C)_{t}\right)$ has a significant positive correlation with $\left(S D_{t}\right)$ (Wald $=5.78(\mathrm{p}=0.028)$ ), probably demonstrating that the appointment of an internal controls expert to a high-level position follows the same logic as that of the appointment of outside directors.

\subsection{Additional Analysis}

The result of the probit analysis illustrates that companies with low-quality internal controls have a motive to enhance governance independence, which implies that when the board understands RDSD, it attempts to enhance its governance independence. This has two interpretations: first, the regulations requiring outside directors and corporate auditors are insufficient; second, the expertise of external directors and corporate auditors is also insufficient. Although the result of Uemura (2013) supports the former interpretation, the latter has still not been examined. If an outside director (or corporate auditor) with expertise does not influence the disclosure of significant deficiencies (improving those deficiencies within a fiscal term), then the regulations might not be enough. To test this hypothesis, a variable (the interaction between outsiders (external directors and corporate auditors) and expertise: OUTSIDE*EXPERT ${ }_{t}$ ) was included in model (9) as follows:

$$
\begin{aligned}
& S D_{t}=F\left(\beta_{0}+\beta_{1} \text { OUTSIDE }^{*} \text { EXPERT }_{t}+\beta_{2} \text { EXPERT }_{-} F(S C)_{t}+\beta_{3} \text { EXPERT_IC }(S C)_{t}\right. \\
& \left.+\beta_{4} \text { EXPERT_IA(SC) }\right)_{t}+\beta_{5} F R_{t}+\beta_{6} M \& A_{t}+\beta_{7} \text { FOREIGN }_{t}+\beta_{8} L N S U B_{t} \\
& \left.+\beta_{9} L N S I Z E_{t}+\beta_{10} R O A_{t}+\beta_{11} G C_{t}+\beta_{12} B_{I} G 4_{t}+\beta_{13} \text { AUDITORS }\right)
\end{aligned}
$$

The fifth to seventh columns in Table 8 show the result of the logistics regression analysis based on model (10) (Hosmer-Lemeshow: $\chi^{2}=9.38(\mathrm{p}=0.31)$, $\left.\mathrm{df}=8\right)$; Cox-Snall: $\left.\mathrm{R}^{2}=0.089(\mathrm{p}=0.178), \mathrm{df}=8\right)$. It shows that $\left(O U T S I D E^{*} E X P E R T_{t}\right)$ has no significant correlation with $\left(S D_{t}\right)$, and therefore even if external directors have expertise, they have no effect on the quality of internal controls.

\section{Discussion}

This study has two main findings. First, companies that have RDSD enhance their governance independence because the boards and top managements have a motive to mitigate any serious economic consequences (e.g., share price, capital cost, audit fees, and management turnover). If governance independence can be enhanced, then their accountability can be satisfied. However, under the JCL, governance independence does not influence internal controls quality. Second, the position of financial expert directors has a significant negative correlation with the disclosure of SD, implying that if a financial expert director holds authority within an organization, then the quality of internal controls is improved by the fiscal year end. On the other hand, the expertise of outside directors and corporate auditors has no effect on the quality of internal controls, which implies that although the authority of the board's discretion is effective in improving internal controls quality, the authority of domestic legislation is not.However, sometimes experts who hold authority can pose a serious risk. For example, there is the possibility that if a financial expert plays a major part in accounting fraud, then that same expert may able to cover up the fraud. Indeed, in the Olympus accounting scandal, a financial expert in a high-level position was heavily involved in the fraud. Neither the Japanese government nor those who establish standards of practice have yet refined the governance system so as to improve the quality of internal controls and to detect accounting fraud. Future research, however, may identify not only the problems with Japanese governance but also the key factors that will improve the effectiveness of governance monitoring.

\section{References}

Ashbaugh, S. H., Collins, D. W., \& Kinney Jr., W. R. (2007). The discover and reporting of internal control deficiencies prior to SOX-mandated audits. Journal of Accounting \& Economics, 44(2), 166-192.

Balsam, S., \& Jiang, A. (2009). Equity incentive and internal control weaknesses. Working Paper, Temple University.

\footnotetext{
${ }^{8}$ The change in the ratio of outside directors from year $t-1$ to $t$ has a negative correlation with remediation of SD in year $\mathrm{t}$ (an indicator variable equal to 1 if the firm reported remediation of SD in year t, and 0 otherwise) (coeff., -0.181 , wald 3.975, $\mathrm{p}=0.046$ ). The sample contains 165 firms that disclosed SD in year $t$.
} 
Beneish M. D., Billings, M. B., \& Hodder, L. D. (2008). Internal control weaknesses and information uncertainty. The Accounting Review, 83(3), 665-703.

Doyle, J. T., Ge, W., \& McVay, S. (2007). Determinants of weaknesses in internal control over financial reporting. Journal of Accounting \& Economics, 44(2), 193-223.

Ge, W., \& McVay, S. (2005). The disclosure of material weaknesses in internal control after the Sarbanes-Oxley Act. Accounting Horizons, 19(3), 159-186.

Hammerseley, J., Meyers, L., \& Shakespere, C. (2008). Market reaction to the disclosure of internal control weaknesses and to the characteristics of those weaknesses under the Section 302 of the Sarbanes-Oxley Act of 2002. Review of Accounting Studies, 13(1), 141-165.

Hoitash, U., Hoitash, R., \& Bedard, J. C. (2009). Corporate governance and internal control over financial reporting: A comparison of regulatory regimes. The Accounting Review, 84(3), 839-867.

Krishnan, J. (2005). Audit quality and internal control: An empirical analysis. The Accounting Review, 80(2), 649-675.

Miyajima, H., \& Ogawa, R. (2012). Nihon kigyo no torishimariyaku kousei no henka wo ikani rikaisuruka ?: Torishimariyakukai kousei no ketteiyouin to shagaitorishimariyaku no dounyu kouka. Discussion Paper Series, Research Institute of Economy, Trade and Industry, IAA.

Ogneva, M., Subramanaam, K. R., \& Raghunandan, K. (2007). Internal control weakness and cost of equity: Evidence from Sox Section 404 disclosures. The Accounting Review, 82(5), 1255-1298.

Saito, T. (2011). Nihon kigyo niyoru syagaitorishimariyaku no dounyu no ketteiyouin to sono kouka. “ Nihon no kigyou touchi: Sono saisekkei to kyousoryoku no kaiyuku ni mukete". Toyo Keizaisya., 181-213.

Uchida, K. (2012). Syagaitorishimariyaku Wariai no Ketteiyouin to Performance. Security Analysts Journal, 4, 3-28.

Uemura, H. (2013). The Quality of Corporate Governance and the quality of Internal Controls. Frontier of Japanese Business Studies: Annual Report of Hitotsubashi University Center for Japanese Business Studies, 9, 103-117.

Uemura, H. (2012). The Characteristics of Material Weaknesses in Internal Controls and Executive Turnover, as well as the Characteristics and Audit Fee. Frontier of Japanese Business Studies: Annual Report of Hitotsubashi University Center for Japanese Business Studies, 8, 103-116.

\section{(cc) $\mathrm{BY}$}

This work is licensed under a Creative Commons Attribution 3.0 License. 